Utah State University

DigitalCommons@USU

\title{
$5-2015$
}

\section{Energy Efficiency and Recovery Opportunities Analysis for Municipal Wastewater Treatment Plant Operations}

Sarah Guzman

Utah State University

Follow this and additional works at: https://digitalcommons.usu.edu/gradreports

\section{Recommended Citation}

Guzman, Sarah, "Energy Efficiency and Recovery Opportunities Analysis for Municipal Wastewater Treatment Plant Operations" (2015). All Graduate Plan B and other Reports. 479.

https://digitalcommons.usu.edu/gradreports/479

This Report is brought to you for free and open access by the Graduate Studies at DigitalCommons@USU. It has been accepted for inclusion in All Graduate Plan B and other Reports by an authorized administrator of DigitalCommons@USU. For more information, please contact digitalcommons@usu.edu.

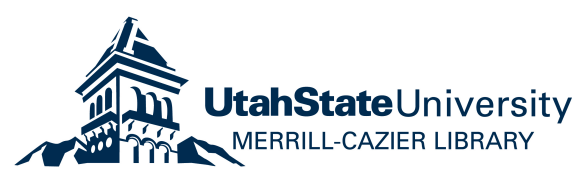




\title{
Utah State University Civil and Environmental Engineering Department
}

\author{
Final Master's Report -Plan B \\ Energy Efficiency and Recovery Opportunities Analysis for Municipal Wastewater \\ Treatment Plant Operations \\ Presented by: Sarah Guzman
}

\author{
Major Advisor: \\ Dr. Michael McFarland
}

Committee Members:

Mr. Lance Wood

Dr. Gilberto Urroz

March 26th, 2015 


\section{TABLE OF CONTENTS}

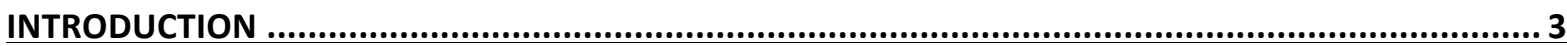

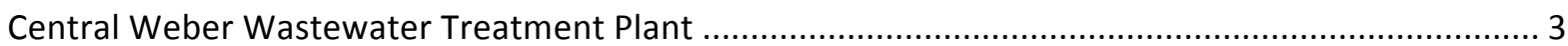

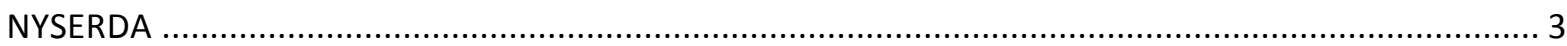

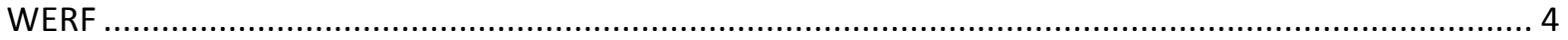

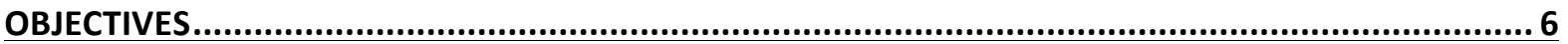

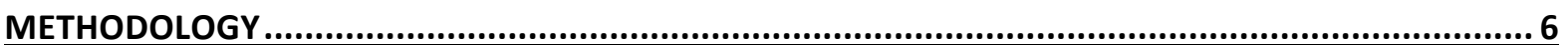

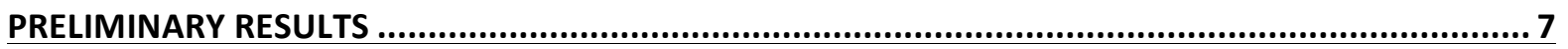

Electrical Energy Usage to Remove Pollutants from Wastewater....................................................... 7

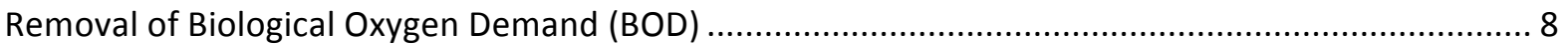

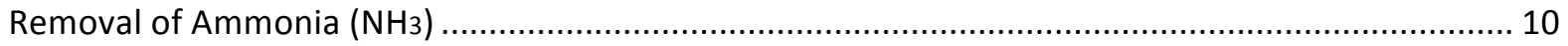

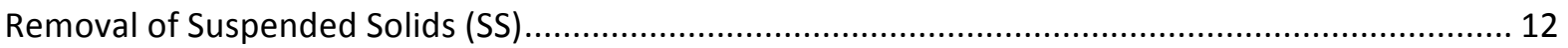

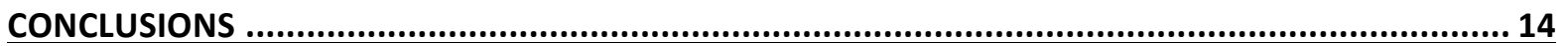

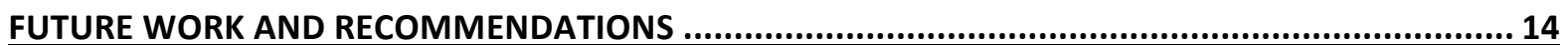

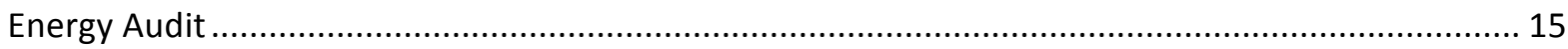

Comparison of Energy Consumption Before and After Expansion ................................................ 16

Evaluation of energy and cost impact on meeting the new proposed ammonia standard ............... 18

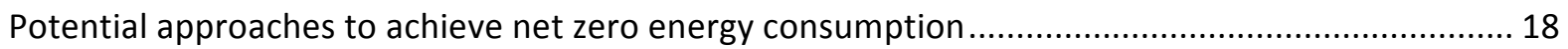

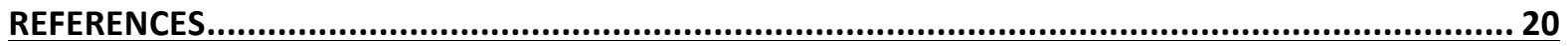




\section{INTRODUCTION}

\section{Central Weber Wastewater Treatment Plant}

Central Weber Sewer Improvement District (CWSID) was built in 1957, offering its sewer treatment services to the residents of Weber and Davis Counties in Northern Utah. The plant serves a population of approximately 213,000 people (MWH Global 2012). The State of Utah Division of Water Quality permits the CWSID.

Originally, Central Weber Sewer Improvement District had a rated wastewater treatment capacity of 45 million gallons per day (MGD) (MWH Global 2014). This wastewater treatment was built in 1959. Due to the population growth of the Weber and Davis counties, Central Weber Sewer Improvement District needed to add additional wastewater treatment capacity into the existing system.

In 2008, CWSID, along with MWH Global, presented a US\$140 millions proposal which described the construction of an additional activated sludge treatment plant; a new headwork's facility and a new raw sludge pump station in order to increment the treatment capacity from 45-MGD to 70-MGD (MWH Global 2014). This project was finished in 2011 and it is estimated that it will support the population demand from Weber and Davis counties until 2025. In addition, these upgrades were required for Central Weber Sewer Improvement District in order to comply the Environmental Protection Agency (EPA) and the State of Utah water regulations.

The expansion of the treatment capacity at the CWSID increases their power consumption. The goals of this report are to evaluate energy usage and efficiency at the Central Weber Sewer Improvement District and to make recommendations that enable the facility to achieve energy neutrality.

\section{New York state Energy Research and Development Authority (NYSERDA)}

The New York State Energy Research and Development Authority (NYSERDA) is a public corporation created in 1975 by the New York State Legislature (NYSERDA 2007). NYSERDA's primary mission is to carry out a broad program of energy research, development and demonstration projects designed to develop and apply efficient technologies to help ensure that New York has secure and economical future supplies of energy, while protecting environmental values and promoting economic growth. 
NYSERDA estimates that municipal wastewater treatment plants (WWTPs) in New York State consume about 1.5 billion kWh of electricity each year (EPA 2013). The baseline electric energy usage that NSYERDA uses is based on several characteristics such as size, method of treatment, source water, etc. Using this methodology, the baseline electric energy use for the sector was estimated to be 2.5 to 3.0 billion kWh per year; roughly two-thirds of the electricity is consumed by wastewater treatment systems (1.75 to 2.0 billion $\mathrm{kWh}$ ). Tables 1 and 2 provide comparisons of electric energy use by size and BOD removal (NYSERDA 2007).

Table 1. Electric Energy Use by Design Capacity - Wastewater Treatment Systems

\begin{tabular}{|c|c|}
\hline Category/Design Capacity & Energy Use (kWh/MG) \\
\hline National Average 1 & 1,200 \\
\hline Statewide Average & 1,480 \\
\hline Less than 1 MGD & 4,620 \\
\hline 1 to 5 MGD & 1,580 \\
\hline 5 to 20 MGD & 1,740 \\
\hline 20 to 75 MGD & 1,700 \\
\hline Greater than 75 MGD & 1,100 \\
\hline
\end{tabular}

Table 2. Electric Energy Use by Secondary Treatment Technology: BOD-based

\begin{tabular}{|c|c|c|c|}
\hline Size Category & $\begin{array}{c}\text { Activated Sludge } \\
\text { (kWh/lb BOD) }\end{array}$ & $\begin{array}{l}\text { Fixed Film (kWh/lb } \\
\text { BOD) }\end{array}$ & $\begin{array}{c}\text { Lagoons (kWh/lb } \\
\text { BOD) }\end{array}$ \\
\hline Less than $1 \mathrm{MGD}$ & 4.1 & 3.3 & 1.5 \\
\hline 1 to $5 \mathrm{MGD}$ & 2.2 & 1.1 & 1.1 \\
\hline 5 to $20 \mathrm{MGD}$ & 1.7 & 1.0 & Not Applicable \\
\hline 20 to $75 \mathrm{MGD}$ & 1.3 & 1.2 & Not Applicable \\
\hline Greater than 75 MGD & 2.0 & Not Applicable & Not Applicable \\
\hline
\end{tabular}

\section{Water Environment Research Foundation (WERF)}

The Water Environment Research Foundation (WERF), a not-for-profit trade organization, funds and manages water quality research for its subscribers through a diverse public-private partnership between municipal utilities, corporations, academia, industry, and the federal government (WERF 2011). WERF subscribers include municipal and regional water and wastewater utilities, industrial corporations, 
environmental engineering firms, and others that share a commitment to cost-effective water quality solutions. WERF is dedicated to advancing science and technology addressing water quality issues as they impact water resources, the atmosphere, the lands, and quality of life.

WERF has a new five-year research plan for energy production and efficiency with the goal of increasing the number of treatment plants that are net energy neutral and to establish energy recovered from wastewater as renewable (WERF 2011). WERF research is looking into types of energy that are available in wastewater, how can it be used or converted, and how to reach energy neutrality at a wastewater treatment plant (WWTP). The energy content of wastewater includes thermal energy, hydraulic energy and chemical energy. In order to achieve energy neutrality, the first step is a "net energy balance," whereby energy needs are balanced by energy supplied. To develop a complete energy balance of the treatment facility, wastewater utility operators, engineers, and process designers must first identify energy needs which can be reduced and then use opportunities to generate or recover energy to supply the remaining treatment needs (WERF 2011). Table 3 summarizes WERF data on the energy opportunity that wastewater treatment plants have depending in the treatment system that they implement.

Table 3. Summary of Energy Recovery Potential (WERF 2011).

\begin{tabular}{|l|c|l|c|}
\hline \multicolumn{1}{|c|}{ Biosolids Technology } & $\begin{array}{c}\text { Percent of Net Energy } \\
\text { "Gap" Reduction Possible }\end{array}$ & $\begin{array}{c}\text { Percent of Net Energy } \\
\text { "Gap" Rechnology }\end{array}$ \\
\hline Anaerobic Digester (AD) Biogas with boilers & $13-57 \%$ & Enhanced solids removal & $10-71 \%$ \\
\hline AD Biogas with cogen engines & $11-61 \%$ & Anaerobic primary treatment & $25-139 \%$ \\
\hline AD Biogas with microturbines & $5-38 \%$ & Heat recovery & $13-49 \%$ \\
\hline AD Biogas with turbines & $7-46 \%$ & Hydraulic & $0 \%$ \\
\hline AD Biogas with fuel cell & $6-42 \%$ & Ammonia as fuel & $-6-12 \%$ \\
\hline AD Biogas after WAS pretreatment & $-2-60 \%$ & Heat from centrate & $13-49 \%$ \\
\hline AD Biogas with Co-digestion & $2-128 \%$ & Microbial fuel cells & $8-110 \%$ \\
\hline Incineration & $2-69 \%$ & Biofuel from algae & $-39-208 \%$ \\
\hline Gasification & $-9-82 \%$ & & \\
\hline
\end{tabular}




\section{OBJECTIVES}

The objectives of this proposal report are:

- To evaluate the potential opportunities to improve energy use at the CWSID

- To analyze the energy associated with removal of pollutants, such as BOD, suspended solids and ammonia, in order to reduce the cost of their removal and increase the saving opportunities for CWSID.

- To quantify the energy use per: million gallons of water treated, pound of BOD removed, pound of ammonia removed, and pound of suspended solids removed.

- To report, analyze and compare different options that may be suitable for the CWSID to achieve energy net neutrality (i.e., to generate internally all the power that they need to treat their wastewater to regulatory standards).

\section{METHODOLOGY}

In order to accomplish the set objectives, the following activities have been pursued:

- Review of the monthly records for electricity and gas consumption by CWSID

- Review of the monthly wastewater flow, BOD, NH3 and Suspended Solids records

- Evaluation of the energy use of specific unit operations associated with pollutant removal

- Comparison of pollutant removal on a total energy use basis and individual unit operation basis

- Consultation with CWSID engineers and operators 


\section{PRELIMINARY RESULTS}

\section{Electrical Energy Usage to Remove Pollutants from Wastewater}

Central Weber Sewer Improvement District provided the needed data sets to calculate the electrical energy usage for the plant. Table 4 shows the average flow rate and the average $\mathrm{kW}$-hr/flow rate and Figure 1 shows the total electrical energy usage in a year basis consumed by CWSID.

Table 4. Electrical Energy usage data form CWSID

\begin{tabular}{|c|c|c|c|}
\hline Month & $\begin{array}{c}\text { Average Flow } \\
\text { Rate (MGD) }\end{array}$ & $\begin{array}{c}\text { Avg kW-hr } \\
\text { (Monthly) }\end{array}$ & kW-hr/MGD \\
\hline Jun-13 & 34 & 916800 & 898.8 \\
\hline Jul-13 & 33.7 & 974400 & 932.7 \\
\hline Aug-13 & 33.5 & 1017600 & 1012.5 \\
\hline Sep-13 & 36.6 & 912000 & 830.6 \\
\hline Oct-13 & 27.5 & 892800 & 1047.3 \\
\hline Nov-13 & 27 & 1003200 & 1238.5 \\
\hline Dec-13 & 25.5 & 1084800 & 1372.3 \\
\hline Jan-14 & 26 & 1233600 & 1530.5 \\
\hline Feb-14 & 30.4 & 1027200 & 1206.8 \\
\hline Mar-14 & 31.1 & 960000 & 995.7 \\
\hline Apr-14 & 28.8 & 1032000 & 1194.4 \\
\hline May-14 & 33.3 & 960000 & 930.0 \\
\hline Jun-14 & 41.4 & 916800 & 738.2 \\
\hline Average & 31.45 & 994707.69 & 1071.41 \\
\hline STD. Dev. & 4.60 & 91476.50 & 225.56 \\
\hline
\end{tabular}

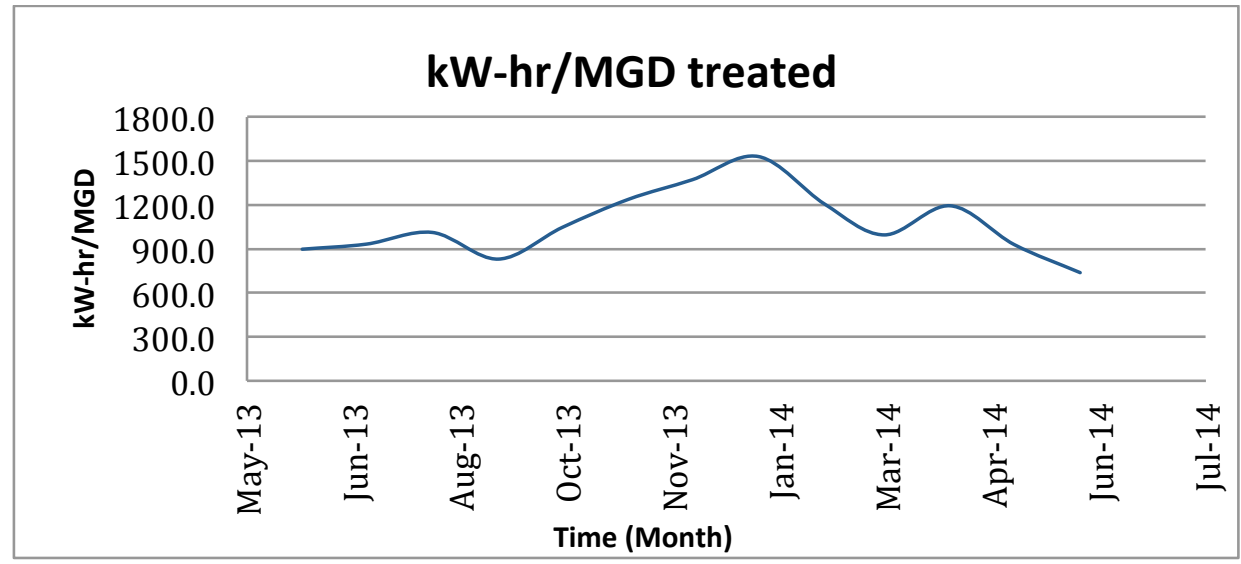

Figure 1. General Electrical Energy Usage in CWSID 
Figure 1 shows that during winter time, the CWSID has a higher energy consumption due to the heating process of the systems.

\section{Removal of Biological Oxygen Demand (BOD)}

The biological oxygen demand reflects the amount of oxygen required by microorganisms during the biological secondary treatment. Table 5 shows the influent and effluent of BOD from the CWSID along with total electrical energy usage for the removal of the pollutant.

Table 5. Electrical Energy Used in BOD Removal in CWSID

\begin{tabular}{|ccccc|}
\hline Month & $\begin{array}{c}\text { Average BOD in } \\
\text { (mg/L) }\end{array}$ & $\begin{array}{c}\text { Avg BOD out } \\
\text { (mg/L) }\end{array}$ & $\begin{array}{c}\text { Ib BOD Removed/ } \\
\text { Month }\end{array}$ & $\begin{array}{c}\text { kW-hr/lb. BOD } \\
\text { removed }\end{array}$ \\
\hline Jun-13 & 117 & 14 & $8.76 \mathrm{E}+05$ & 1.05 \\
\hline Jul-13 & 118 & 12 & $9.24 \mathrm{E}+05$ & 1.06 \\
\hline Aug-13 & 108 & 10 & $8.21 \mathrm{E}+05$ & 1.24 \\
\hline Sep-13 & 116.2 & 10 & $9.73 \mathrm{E}+05$ & 0.94 \\
\hline Oct-13 & 146 & 7 & $9.88 \mathrm{E}+05$ & 0.90 \\
\hline Nov-13 & 183 & 8 & $1.18 \mathrm{E}+06$ & 0.85 \\
\hline Dec-13 & 203 & 13 & $1.25 \mathrm{E}+06$ & 0.87 \\
\hline Jan-14 & 162 & 11 & $1.02 \mathrm{E}+06$ & 1.22 \\
\hline Feb-14 & 156 & 14 & $1.01 \mathrm{E}+06$ & 1.02 \\
\hline Mar-14 & 143 & 14 & $1.04 \mathrm{E}+06$ & 0.93 \\
\hline Apr-14 & 166 & 12 & $1.11 \mathrm{E}+06$ & 0.93 \\
\hline May-14 & 134 & 13 & $1.04 \mathrm{E}+06$ & 0.92 \\
\hline Jun-14 & 97 & 11 & $8.91 \mathrm{E}+05$ & 1.03 \\
\hline Average & 142.25 & 11.46 & $1.01 \mathrm{E}+06$ & 1.00 \\
\hline Std. Dev. & 31.23 & 2.26 & $1.22 \mathrm{E}+05$ & 0.12 \\
\hline
\end{tabular}

In order to analyze the total energy needed for BOD removal in CWSID, the unit operations involved in the removal of the pollutant were analyzed. Table 6 shows the electrical energy usage for the main unit operations analyzed. 
Table 6. Electrical Energy Consumed by BOD removal Unit Operations

\begin{tabular}{|c|c|}
\hline Unit Operation & kW-hr/lb BOD \\
\cline { 2 - 2 } & Average \\
\hline Blowers & 0.27 \\
\hline Mixers & 0.01 \\
\hline WAS Pump & 0.24 \\
\hline Influent Pump & 0.20 \\
\hline Raw Sludge Pump & 0.02 \\
\hline
\end{tabular}

Figure 2 shows the comparison between the total electrical energy usages at the CWSID with the electrical energy use in the removal of BOD.

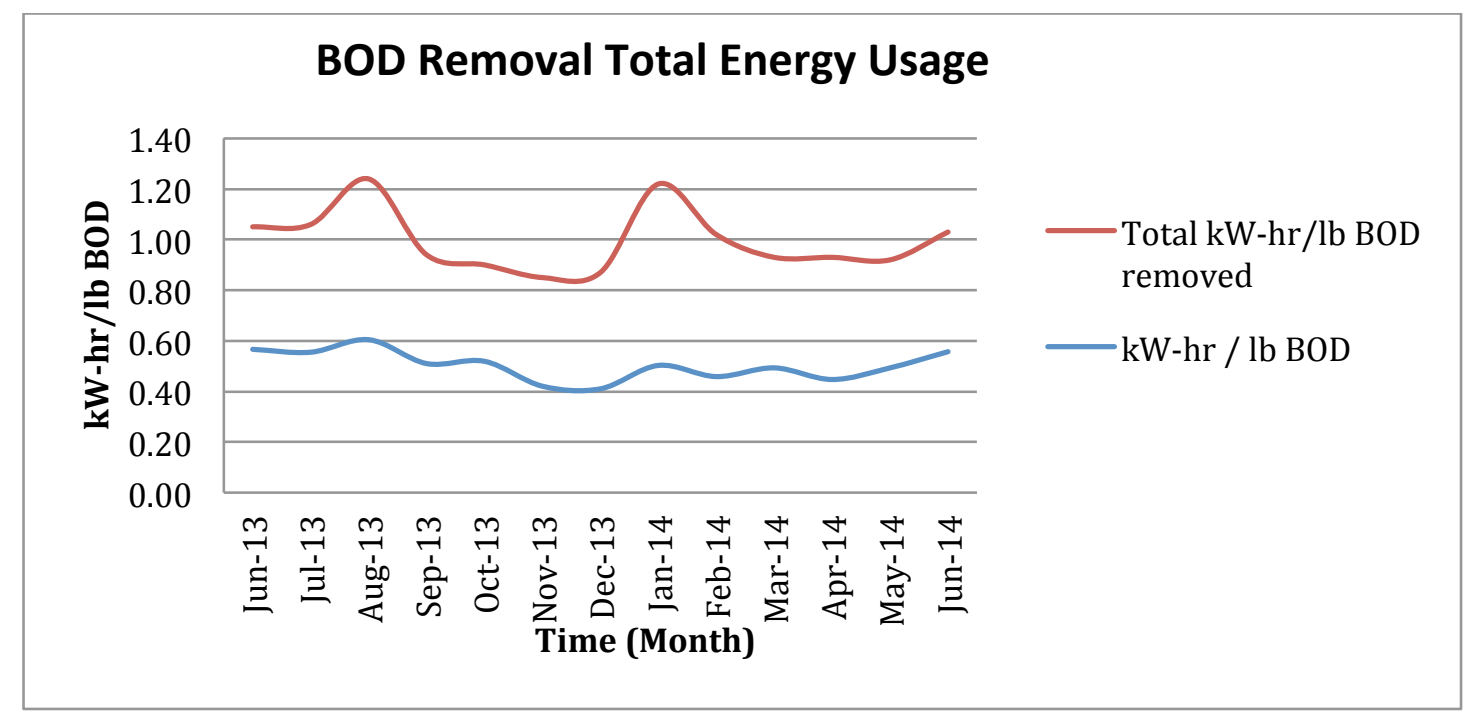

Figure 2. Total Energy Usage associated with BOD Removal

Figure 2 summarizes the total electrical energy consumed by CWSID (red line) and compares it to the electrical energy usage use in BOD removal. The difference between the two lines represents the opportunities that exist for CWSID to save energy. Figure 2 indicates that the energy usage will vary seasonally. During summer and winter time, more energy is required due to the cooling and heating demands of the facilities buildings. 


\section{Removal of Ammonia (NH3)}

Ammonia is a pollutant normally found in municipal wastewater. Sources of ammonia include fertilizers, sanitary waste, cleaners, industrial waste, etc. In aerobic wastewater treatment, ammonia is oxidized to nitrate and then to nitrite. The current ammonia limit discharge for wastewater permitted by the Utah Division Quality is $4.5 \mathrm{mg} / \mathrm{L}$ (Allen 2013). The new EPA proposed limit for ammonia is $1.9 \mathrm{mg} / \mathrm{L}$ and it is based on the need to protect fresh water mussels and clams. This change is expected to happen in 2019 or 2020 (Allen 2013). Table 7 shows the influent and effluent ammonia concentration at the CWSID along with total electrical energy usage for the removal of the pollutant.

Table 7. Electrical Energy Used in Ammonia Removal in CWSID

\begin{tabular}{|c|c|c|c|c|}
\hline & & & & \\
2 & kW-hr/lb \\
Month & Avg NH3 in (mg/L) & Avg NH3 out (mg/L) & lb NH3 Removed/ Month & removed \\
\hline Jun-13 & 9.94 & 3.34 & $5.61 \mathrm{E}+04$ & 16.3 \\
\hline Jul-13 & 8.99 & 2.74 & $5.45 \mathrm{E}+04$ & 17.9 \\
\hline Aug-13 & 9.07 & 2.27 & $5.70 \mathrm{E}+04$ & 17.9 \\
\hline Sep-13 & 9.46 & 2.53 & $6.35 \mathrm{E}+04$ & 14.4 \\
\hline Oct-13 & 12.94 & 1.67 & $8.01 \mathrm{E}+04$ & 11.1 \\
\hline Nov-13 & 15.79 & 0 & $1.07 \mathrm{E}+05$ & 9.4 \\
\hline Dec-13 & 16.78 & 0 & $1.11 \mathrm{E}+05$ & 9.8 \\
\hline Jan-14 & 15.79 & 4.7 & $7.45 \mathrm{E}+04$ & 16.5 \\
\hline Feb-14 & 13.47 & 5.54 & $5.63 \mathrm{E}+04$ & 18.2 \\
\hline Mar-14 & 11.73 & 5.22 & $5.23 \mathrm{E}+04$ & 18.3 \\
\hline Apr-14 & 11.7 & 4.06 & $5.51 \mathrm{E}+04$ & 18.7 \\
\hline May-14 & 9.37 & 4.12 & $4.52 \mathrm{E}+04$ & 21.2 \\
\hline Jun-14 & 8.8 & 2.9 & $6.11 \mathrm{E}+04$ & 15.0 \\
\hline Average & 11.83 & 3.01 & $6.72 \mathrm{E}+04$ & 15.8 \\
\hline Std. dev. & 2.77 & 1.70 & $2.06 \mathrm{E}+04$ & 3.7 \\
\hline
\end{tabular}

The electrical energy usage needed to remove one pound of ammonia is high in comparison with other regulated pollutants. After compiling the ammonia data from NYSERDA and WERF, Table 8 shows the values where CWSID has an ammonia removal value that is twice higher than the national average (WERF) and the data reported by NYSERDA. 
Table 8. Ammonia Data Comparison Table

\begin{tabular}{|c|c|c|c|}
\hline $\mathbf{k W}-\mathbf{h r} / \mathbf{l b}$ & NYSERDA & WERF & CWSID \\
\hline $\mathrm{NH3}$ & 5.8 & 6.6 & 15.8 \\
\hline
\end{tabular}

The high electrical energy used in the removal of ammonia is a disturbing fact that can affect CWSID when the new proposed ammonia standard is promulgated. The current ammonia standard is $4.5 \mathrm{mg} / \mathrm{L}$ of ammonia and the CWSID is currently using two times more energy than the energy used to remove ammonia in the state of New York. If the proposed ammonia standard is approved, CWSID will increase their energy usage associated with ammonia removal. In order to analyze the total energy needed for ammonia removal in CWSID, the unit operations involved in the removal of the pollutant were analyzed. Table 9 shows the electrical energy usage for the main unit operations analyzed.

Table 9. Electrical Energy Consumed by Ammonia removal Unit Operations

\begin{tabular}{|c|c|}
\hline \multirow{2}{*}{ Unit Operation } & $\mathrm{kW}-\mathrm{hr} / \mathrm{lb} \mathrm{NH3}$ \\
\cline { 2 - 2 } Blowers & Average \\
\hline Mixers & 4.24 \\
\hline
\end{tabular}

Figure 3 shows the comparison between the total electrical energy used in CWSID with the electrical energy use in the removal of ammonia.

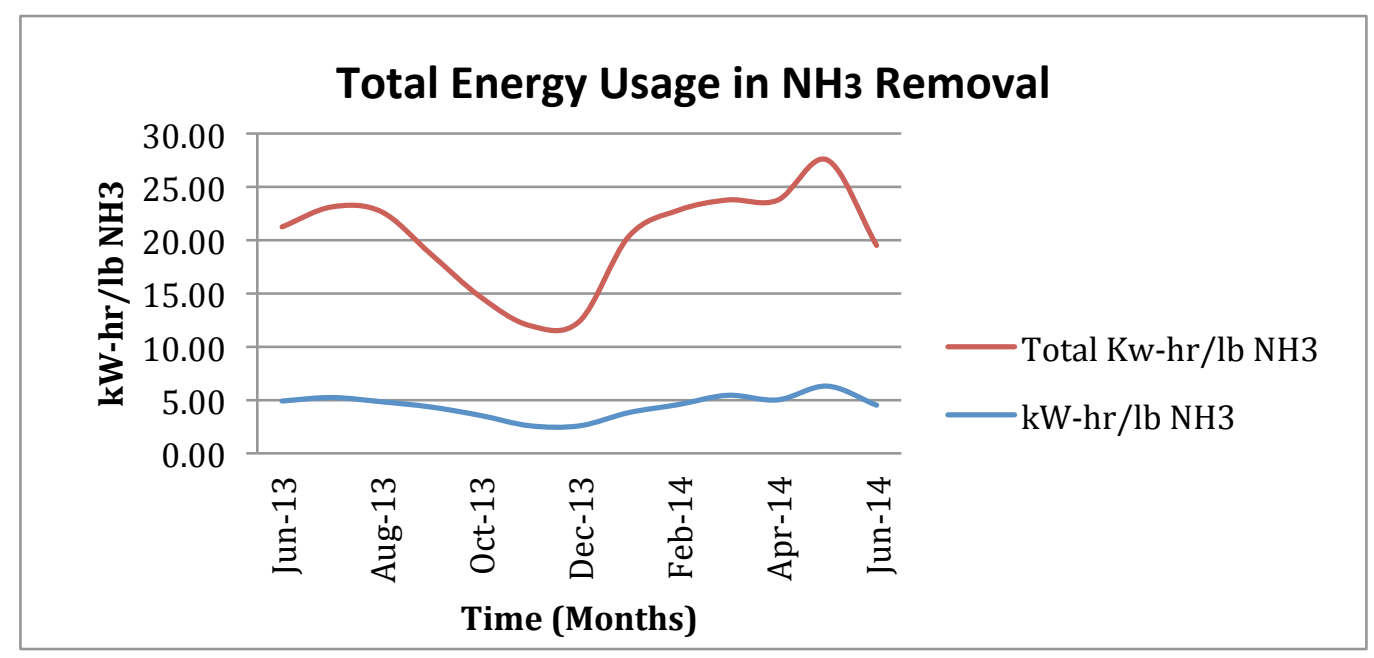

Figure 3. Total Energy Usage associated with Ammonia Removal 
Figure 3 shows the total electrical energy consumed by CWSID (red line) and compares it to the electrical energy usage use in ammonia removal. The difference between the two lines represents the potential energy saving opportunities available to CWSID.

Figure 3 shows that during summer time there is less energy consumed in the ammonia removal process than during winter time. This variation may be due to the use of fewer pumps during summer time since the flow rate is lower than during winter time. It can also indicate that more ammonia is removed through volatilization during the summer months and therefore less aeration is needed to remove ammonia.

\section{Removal of Suspended Solids (SS)}

Suspended solids are the particles that remain suspended in water. The removal of suspended solids has an important role in wastewater treatment because suspended solids are major carriers of pathogens. CWSID removes their suspended solids by sedimentation. Table 10 shows the influent and effluent concentrations of suspended solids in CWSID along with total electrical energy usage for the removal of the pollutant.

Table 10. Electrical Energy Used in Suspended Solids Removal in CWSID

\section{Month Avg SS in (mg/L) Avg SS out (mg/L) lb SS Removed/ Month kW-hr/lb SS removed}

\begin{tabular}{|c|c|c|c|c|}
\hline Jun-13 & 120 & 9 & $9.44 \mathrm{E}+05$ & 0.97 \\
\hline Jul-13 & 127 & 8 & $1.04 \mathrm{E}+06$ & 0.94 \\
\hline Aug-13 & 128 & 7 & $1.01 \mathrm{E}+06$ & 1.00 \\
\hline Sep-13 & 138 & 7 & $1.20 \mathrm{E}+06$ & 0.76 \\
\hline Oct-13 & 159 & 5 & $1.09 \mathrm{E}+06$ & 0.82 \\
\hline Nov-13 & 207 & 6 & $1.36 \mathrm{E}+06$ & 0.74 \\
\hline Dec-13 & 224 & 6 & $1.44 \mathrm{E}+06$ & 0.75 \\
\hline Jan-14 & 198 & 6 & $1.29 \mathrm{E}+06$ & 0.96 \\
\hline Feb-14 & 183 & 7 & $1.25 \mathrm{E}+06$ & 0.82 \\
\hline Mar-14 & 190 & 9 & $1.46 \mathrm{E}+06$ & 0.66 \\
\hline Apr-14 & 213 & 7 & $1.48 \mathrm{E}+06$ & 0.70 \\
\hline May-14 & 174 & 8 & $1.43 \mathrm{E}+06$ & 0.67 \\
\hline Jun-14 & 108 & 8 & $1.04 \mathrm{E}+06$ & 0.89 \\
\hline Average & 166.85 & 7.15 & $1.23 \mathrm{E}+06$ & 0.82 \\
\hline Std. Dev. & 37.70 & 1.17 & $1.92 \mathrm{E}+05$ & 0.12 \\
\hline
\end{tabular}


In order to analyze the total energy needed for suspended solids removal in CWSID, the unit operations involved in the removal of the pollutant were analyzed. Table 11 shows the electrical energy usage for the main unit operations analyzed.

Table 11. Electrical Energy Consumed by Suspended Solids removal Unit Operations

\begin{tabular}{|c|c|}
\hline \multirow{2}{*}{ Unit Operation } & $\mathrm{kW}$-hr/lb SS \\
\hline WAS Pump & Average \\
\hline Raw Sludge Pump & 0.24 \\
\hline Blowers & 0.02 \\
\hline Mixers & 4.24 \\
\hline
\end{tabular}

Figure 4 shows the comparison between the total electrical energy used in CWSID with the electrical energy use in the removal of suspended solids.

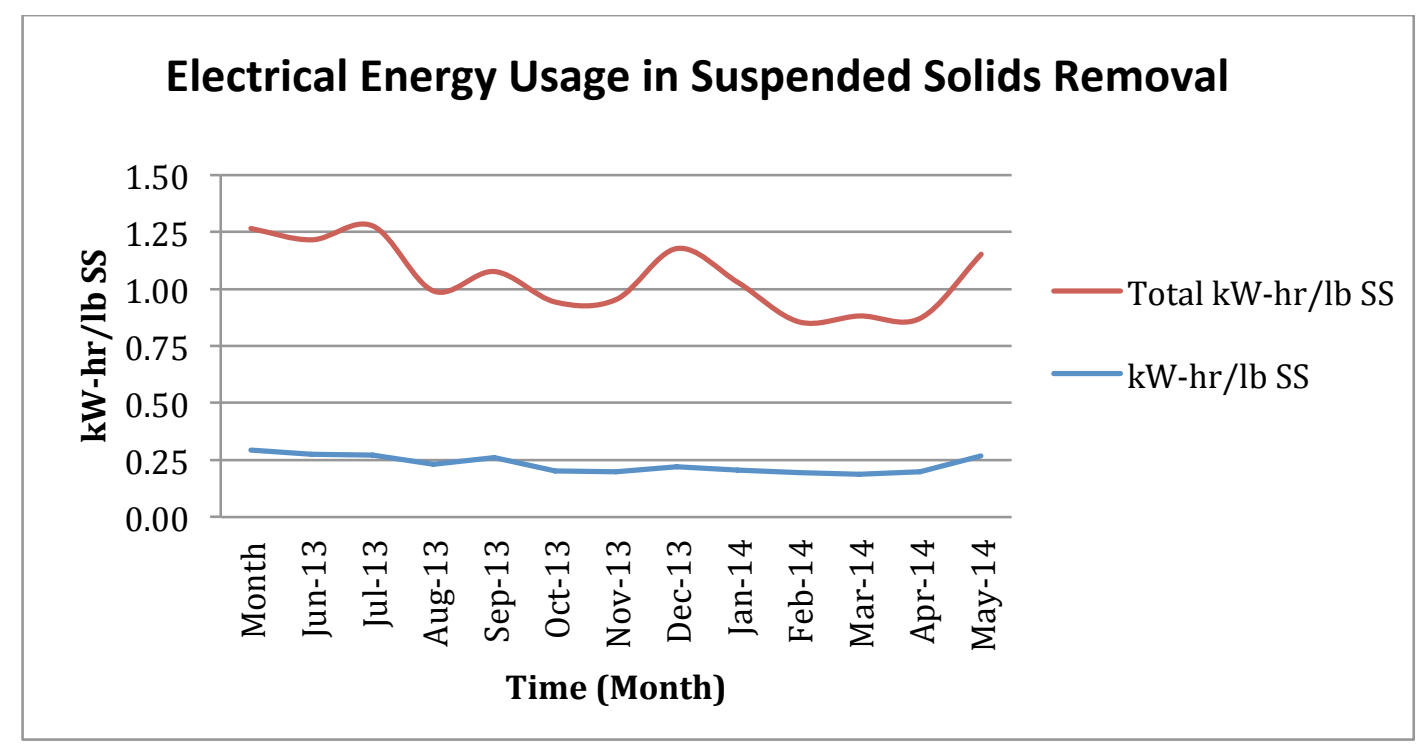

Figure 4. Total Energy Usage associated with Suspended Solids Removal

Figure 4 shows the total electrical energy consumed by CWSID (red line) and compares it to the electrical energy usage use in suspended solids removal. The difference between the two lines represents the opportunities that CWSID can use to save energy. It can be observed in Figure 4 that total energy consumption in the CWSID varies according to the season of the year. There are increase of energy consumption during summer and winter time due to space cooling and heating needs. 
After analyzing the electrical energy use by CWSID, it can be concluded that achieving water quality standards has an important and significant energy cost. This cost depends on the energy demand, which varies based on the pollutant that you want to remove and/or flow rate of the wastewater plant. In addition, when comparing energy demand based on unit operations versus total plant demand, there exist an opportunity for energy reduction. Based on energy evaluation, CWSID is very efficient in BOD and suspended solids removal and overall treatment of wastewater. Based on ammonia removal, there appears to be significant opportunities for energy efficiency at CWSID. Due to the new ammonia standard, energy efficiency associated to $\mathrm{NH}_{3}$ removal is highly important since energy costs will increase.

\section{RECOMMENDATIONS}

Based on these preliminary results, we recommend the following:

- Conduct a detailed energy audit on those processes in the plant expansion processes in Central Weber Sewer Improvement District

- Compare energy consumption before and after the expansion

- Evaluate potential approaches for achieving net zero energy consumption

- Evaluate the energy and cost impact on meeting the new proposed ammonia standards 


\section{Energy Audit}

An energy audit is an evaluation of the energy usage of a facility. In order to evaluate and compare the energy consumption of CWSID before and after the expansion, an energy audit in certain areas of the facility was needed. The data on Table 12 was collected based on an energy audit performed to the CWSID in 2013 by Wood * Richards and Associates.

Table 12. CWSID Expenses in their Operational System

\begin{tabular}{|c|c|c|c|}
\hline \multicolumn{2}{|c}{2012} & 2013 & \% Change \\
\hline Operation and Management & $1,027,965$ & $1,050,239$ & $2 \%$ \\
\hline Pretreatment & 190,875 & 218,595 & $15 \%$ \\
\hline Utilities and Services & $1,405,899$ & $1,646,099$ & $17 \%$ \\
\hline
\end{tabular}

According to Table 12, the expenses of the operational system increased after the 2012 expansion. This said, the CWSID could look into potential approaches to lower these expenses. If no actions are taken and a projection of these expenses is made in a timeline of 2 more years, the $\%$ change will increase as Figure 5 shows.

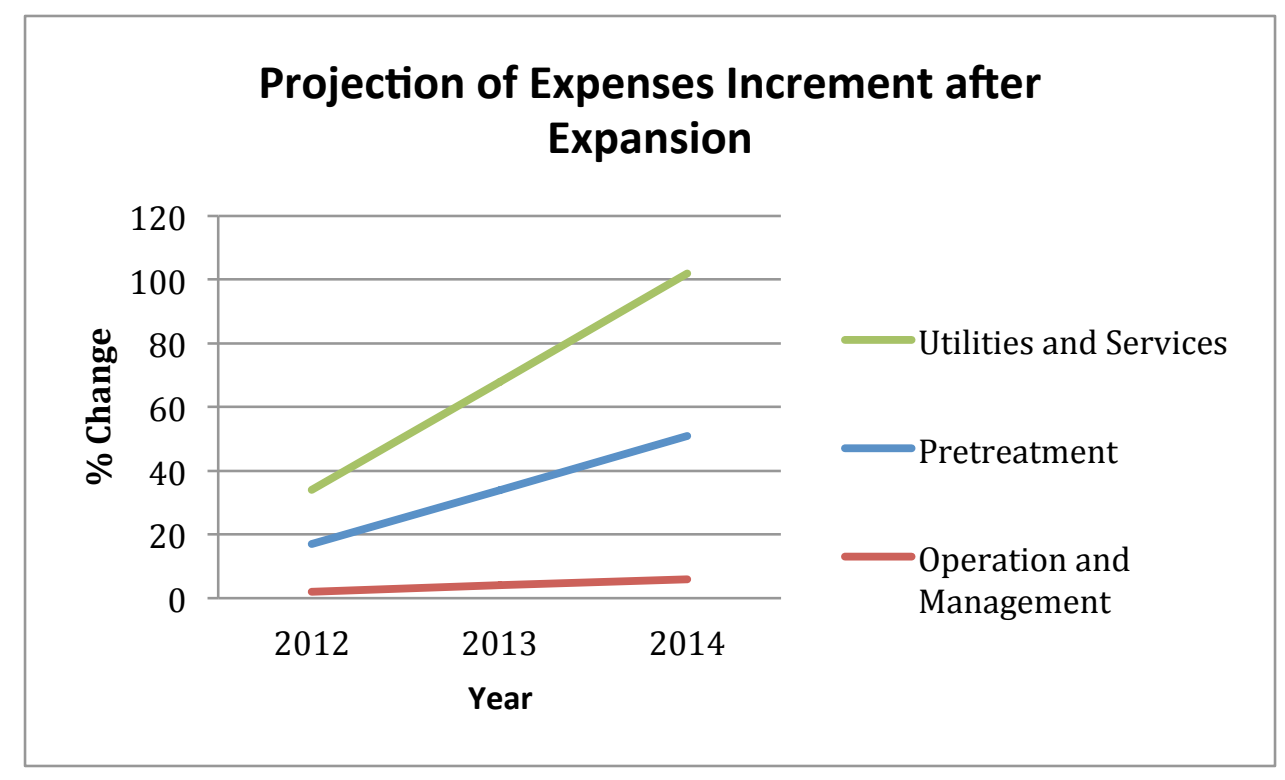

Figure 5. Projection of Expenses Increment in the CSID after the Expansion 


\section{Comparison of Energy Consumption Before and After Expansion}

Central Weber Sewer Improvement District improved its treatment system from trickling filters to anaerobic digester. This expansion took place in Fall 2011 and it was finalized in Summer 2012, with an estimated cost of $\$ 150$ millions. Before the expansion took place, the CWSID had an average electrical energy consumption of 45,5000 kW-hr per year, which cost to CWSID $\$ 310,000$ per year. Figure 6 shows the relation between the energy consumption versus the energy cost.

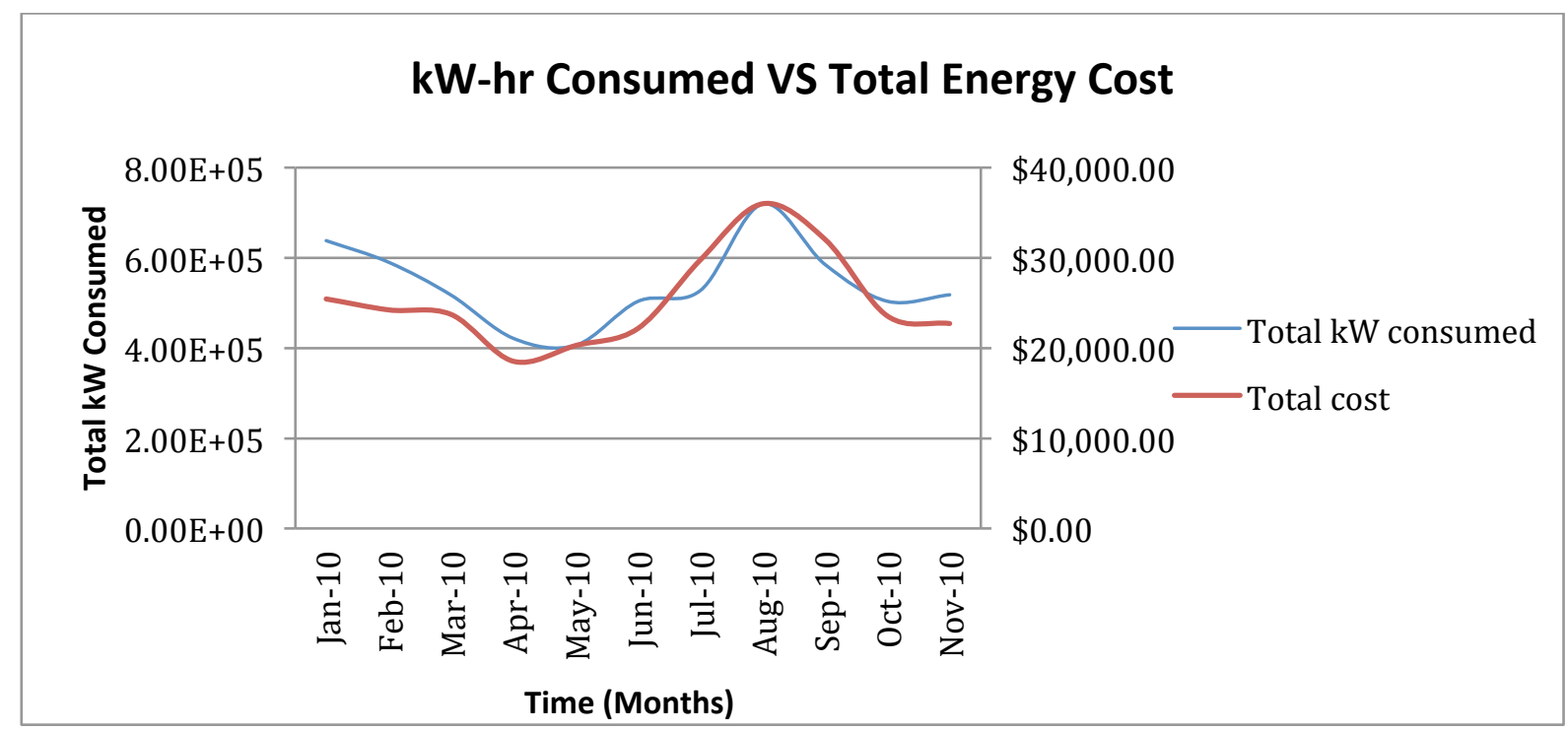

Figure 6. Energy Consumption and Energy Cost before the Expansion

After the expansion was finalized, the CWSID experienced a significant increase in the consumption of electrical energy. The CWSID increased its electrical energy consumption to an average of 1,000,000 kWhr per year, generating a cost of $\$ 660,000$ per year. Figure 7 shows how the electrical energy consumption significantly increases after the expansion. 


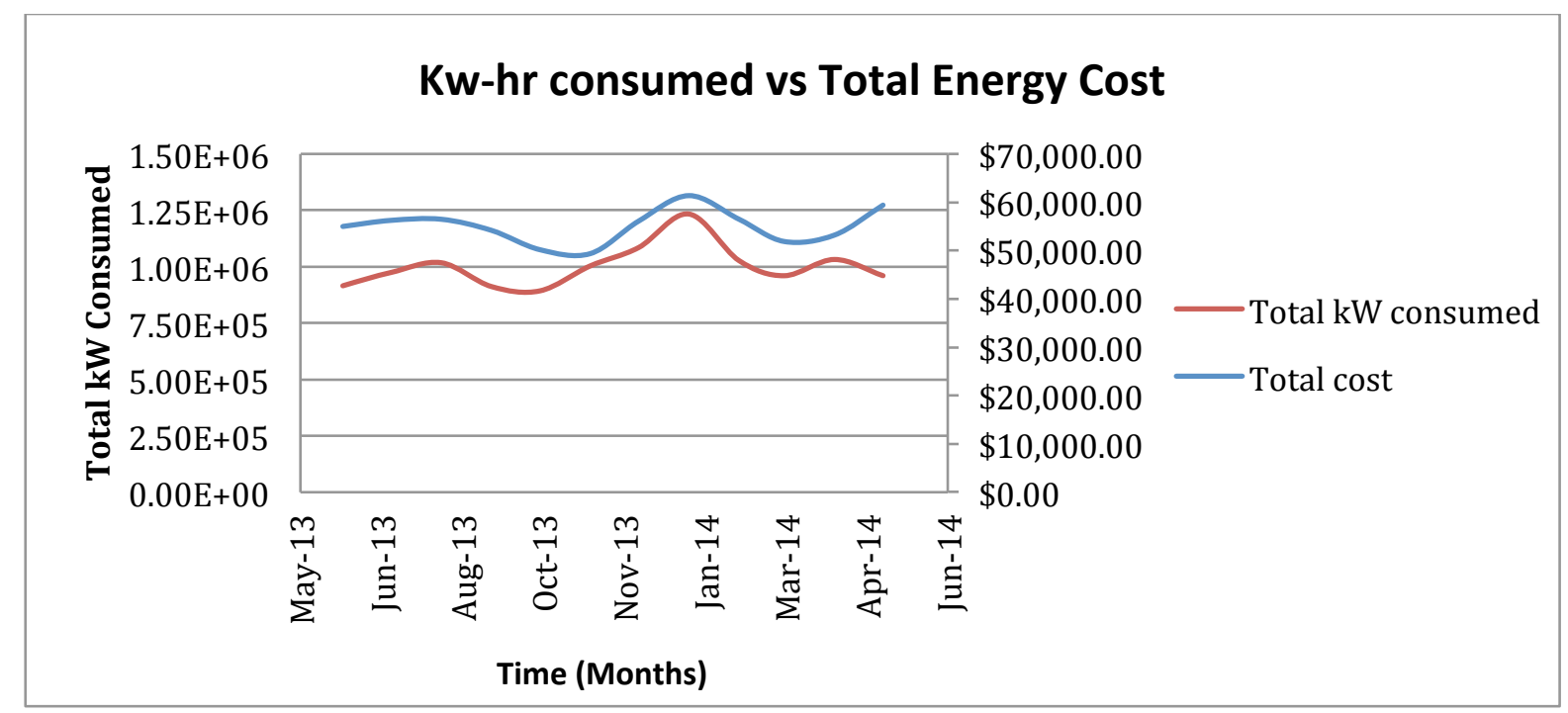

Figure 7. Energy Consumption and Energy Cost after the Expansion

Figure 8 compares the energy usage in CWSID before and after the expansion. It is noticeable how the energy consumption more than triples after the expansion. This suggests that there is energy savings opportunity in the current CWSID treatment system.

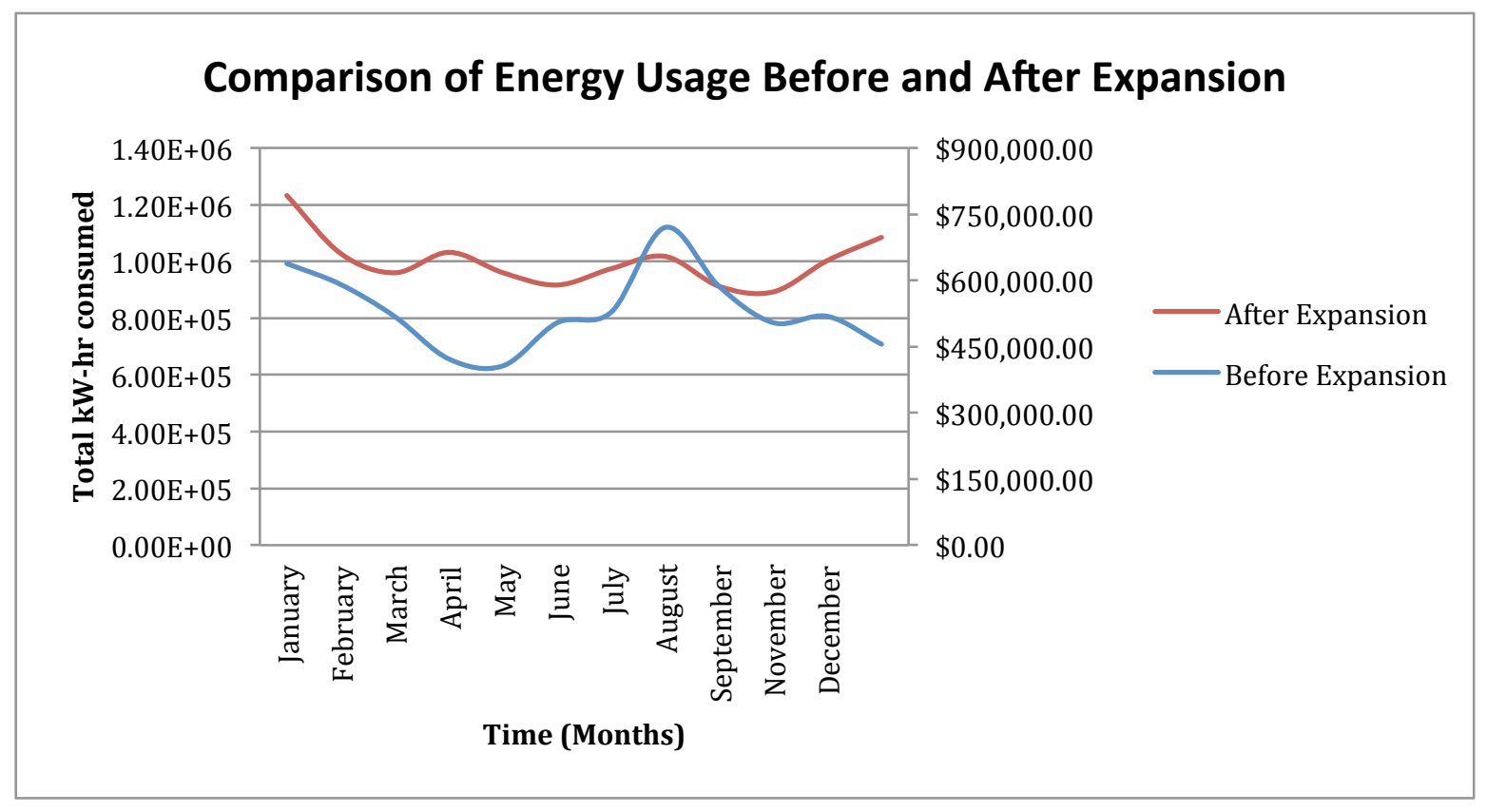

Figure 8. Comparison of Energy Usage Before and After the Expansion 
Figure 8 shows a clear difference in the energy consumption in the CWSID before and after the expansion. Before the expansion, there was more variation during the seasons. This happened because the trickling filters the CWSID used were not very efficient during cold seasons. When the plant moved to an activated sludge system, the energy consumption stabilized even though the cost of the energy consumption is significantly higher. This aspect is what gives to the CWSID opportunity to reduce the cost and look into approaches to produce more energy.

\section{Evaluation of energy and cost impact on meeting the new proposed ammonia standard}

As discussed previously in the report, the CWSID is using an average of $15.8 \mathrm{~kW}-\mathrm{hr} / \mathrm{lb} \mathrm{NH}$ removed in order to meet the current $\mathrm{NH}_{3}$ standard of $4.5 \mathrm{mg} / \mathrm{L}$ in their treated water. Nevertheless, a new ammonia standard of $1.9 \mathrm{mg} / \mathrm{L}$ has been proposed in order to improve the quality of the treated water. This said, the CWSID would have to look into energy opportunities in order to reduce the energy consumption in the nitrification process. If the CWSID keeps the same average flow rate of 31 MGD and tries to meet the new ammonia standard with their current system, the energy consumption involved in the ammonia removal process will increase from 1.5 millions $\mathrm{kW}$-hr per year to 4.6 million $\mathrm{kW}$-hr per year.

\section{Potential approaches to achieve net zero energy consumption}

Achieving net zero energy is a demanding and intensive goal for any industry. In the wastewater treatment plants, there are different sources that help to accomplish this target, such as the use of solar panels, Eolic energy, cogeneration systems, among others. The CWSID is already producing around $18 \%$ of the total energy that the plant consumes by using two cogeneration engines. The cogeneration engines run based on waste that is collected from the water treatment. The main issue for the CWSID is to find energy opportunities that help it to increase the self-energy production in order to achieve the net zero energy consumption. Some potential recommendations for the CWSID go power neutral are:

- To add two more cogeneration engines. This addition can increase the energy production in the CWSID. However, the cost benefit of getting two more engines will depend in the efficiency of the plant and its energy consumption. This can be proposed for future research.

- The CWSID requires around 1,000,000 kW-hr of electricity per year to run the entire plant. Currently, they are producing enough energy to generate $18 \%$ of the total energy consumption $(180,000 \mathrm{~kW}$-hr/year). The CWSID uses organic food waste from local food companies as fuel to 
generate methane for the cogeneration engines. In order to generate more energy, the CWSID can add more organic food waste to the engines. The challenge here is how they can get enough organic food waste to increase the energy production of their cogeneration system. According to recent studies at the CWSID, $10 \%$ based on COD of organic waste increase the biogas production by almost $40 \%$. This is a very promising option for the CWSID to look into for future work on approaching net zero energy. This scenario can be proposed for future research. 
1. Allen, M. (2013). "Minutes of the Meeting $f$ the Trustees of the Central Weber ewer Improvement District." http://www.centralweber.com/images/stories/minutes/oct13min.pdf

2. Central Weber Sewer Improvement District Cogeneration Plant Optimization Study - Final Report (CWSID-WWTP-12-01) (2012) MWH Global - Salt Lake City, UT

3. Energy Center of Wisconsin, Energy-Saving Opportunities for Wastewater Facilities: A Review, June 2003.

4. Energy Efficiency in Water and Wastewater Facilities (2013) US Environmental Protection Agency http://www.epa.gov/statelocalclimate/documents/pdf/wastewater-guide.pdf

5. Energy Index Development for Benchmarking Water and Wastewater Utilities (2007) AWWA Research Foundation, California Energy Commission and the New York State Energy Research and Development Authority (NYSERDA) http://www.nyserda.ny.gov/Energy-Efficiency-andRenewable-Programs/Commercial-and-Industrial/Sectors/Municipal-Water-andWastewater/MWWT-Tools-and-Materials.aspx

6. Implementing Utah's Nutrient Control Strategy (2014) Utah Department of Environmental Quality, http://www.deq.utah.gov/Topics/FactSheets/docs/handouts/implementingstrategy.pdf

7. MWH Global (2014). "Central Weber Wastewater Plant Expansion." MWH Global http://www.mwhglobal.com/mwh-projects/central-weber-wwtp-upgrade. July $10^{\text {th }}, 2014$

8. Water Design-Build Council (2013). "Ogden Central Weber Improvement District (UT)." Water Design-Build Council. http://www.waterdesignbuild.com/water-design-build-projects/ogdencentral-weber-sewer-improvement-district-ut/. August $1^{\text {st }}, 2014$

9. Water Environment Research Foundation (2011). Exploratory Team Report - Energy Management. 
10. Wood*Richards and Associates (2013). Central Weber Sewer Improvement District basic Financial Statements with Independent Auditor's reports year ended December 31, 2013. http://www.centralweber.com/images/2013audit.pdf. February 28th, 2015 